\title{
醸造試験所と技術の今昔 $(\mathrm{V})$
}

\author{
国税庁醸造試験所 村 上 英 也
}

\section{創立 70 年まで}

原料関係では, 米の豊作が続いて多量の古（古）米が 余ったというので合の酒造適性の試験を行っていたが, 現在は白米を入荷して使用することが多くなり，精米歩 合や品種の鑑定法規格の設定を目指し, 進んで油脂分の 発酵化学的变化や省エネルギーのための経済的 $\alpha$ 化方法 を研究している。また, 水中鉄分の存在形態を研究し, 従来からある種々の浄水法がもっていた欠陷を鉄の形態 に応ずるように改善して品質の向上に役立てている。

微生物関係では, 菻菌（オリゼー）の多变量解析に上 る新分類法を設けて従来同一視されてきたフラブスから 明確に区別し，後者だけがアフラトキシンを造ることを 證明し,これら野性菌の検出培地を案出して䁔造業界の 不安を一掃し、またフェリクロームや火落酸を生産しな い麴菌変異株を造成して, 着色の少ない火落ちしにくい 清酒の醇造に利用している。䴯菌の増殖特性を明らかに し，また愁の褐変は愁菌キロシナーゼによるチロシンか らドーパ及びプロトカテキュ酸の生成によって起り, 黒 粕はこの他にドーパとアセトアルデヒドから導びかれる インドキノリン骨格の新物質が加わって起ることを證明 した。次に酵母では，保存酵母の整理を計画するとと むに，新しい技法を開発して種々の優良清酒酵母（有 泡）から優良泡ナシ酵母を造成して実際の酒造工場で利 用しタンク容量の節約に役立てているし，また遺伝学的 に優良酵母にキラー性（不良酵母に殺されない性質）を 付与する研究を行なっている。火落菌については，GC 量や細胞壁成分を比較して $\mathrm{pH}$ ・資化性糖・好アルニー ル性などをkeyとする新分類法を設けて整理し, 検出培 地を開発して污染経路を追跡し, また, サリチル酸に代 る新しい防腐剤としてラウリルバリネートほか数種の有 用なものを見つけたが, 火入れ貯蔵法の改善によって保 存の目的が充分に達しられるようになったので 48 年 2 月省令を改正してサリチル酸の使用を禁止した。

成分では, 日光着色の機構について数種のアミノ酸・ フラビン・キヌレン酸などの光感系, これにデフェリフ エリクローム・Mn の加わる接触系, およびインドール 酢酸・プロトカテキュ酸などの酸化系のあることを認 め, また清酒の青色蛍光性物質の主体はトリプトファン
とアルデヒドの光化学反応によって生成するハルマンで あり，熟成によって増加することを證明した。な报，熟 成した清酒中に多い新しい成分として, 苦味物質にプロ リルロイシン無水物や数種のペプチドを分離し，ゴク味 物質にコハク酸エチル・ジメチルジサルハイドその他を 認め, 進んで熟成香の本体を追求し，また熟成の進行測 定に 3-デオキシグルコソン量を指標とする方法を提案 した。また清酒の味覚構成には甘辛, 濃淡, およびロ゙ク 味の 3 者が有力な成分であることを推計学的に立證し， 前二者については日本酒度と酸度との関係から適確に数 表化する方法を発表した。

資材・工学関係では，活性炭素の使用効率を高めるた めに 2 段向流法や，粒状炭を塔につめて再生利用する方 法をひらき，また色素の吸着力試験用に，清酒に適した 標準着色液（トリプトフアン・メラノイジン）を開発 し，また市眅酵素剤の成分規格や配合の影響を検討し， 細胞壁溶解酵素を精製し，また白ボケの清澄に用いる杮 渋の定量法を定め進んで代替物の開発につとめている。 また酒造経過に伴なう方方文中の微生物と成分の消長を 追究して半連続式醸造法の基礎を, また, 発酵と基質溶 解・熱伝導などの工学的研究によって大型タンクの温度 制御方式を提供した。次に公害対策として, 高分子化合 物と塩化第 2 鉄を併用する洗米廃水の凝集沈殿法を開発 して普及に努めている。

果実酒に関しては, 低温性酵母の開発, 輸入濃縮果汁 や干しぶどうの醇造適性, $\mathrm{SO}_{2}$ を節減する醇造法の改 良, 不良産膜酵母の性質, 酸化臭の発生に対する銅イオ ンその他の影響, 酸味と緩衝能の関係, 新しい果実の利 用などを研究している。本邦固有の蒸留酒である乙類焼 酎は, 昭和 47 年 5 月に沖繩県の本土復帰などのことる ありその消費が伸びているが，内地古米の泡盛醸造適性 について本来使用のタイ砕米と比較してその特性を明ら かにし, 進んで油臭の成因, 黒椈菌の性質などの研究を 行ないまたウイスキーに関しては，その熟成に関与す る成分スコポラミン（蛍光性）やメチルオクタラクトン (熟成香味)などを分離し，さらにその前駆物質の追究 を行っている。 


\section{品評会のこと}

清酒の品評会や鑑評会が全国的規模で行なわれたの は, 明治 40 年秋の清酒品評会（日本醇造協会主催）が 最初であり，44 年春からは全国新酒鑑評会も発足した。 第 1 回品評会では，長部文治郎ら 7 人の酒造家主人が審 査員となって 2,138 点を半月間で審查したが，この経過 を見た初代庶務課長上林敬次郎（前秋田税務管理局長） はその総合所見として, 審查全点数は 500 位, 1 人 1 日 の唎酒点数は 50 位が適正であり, 唎酒には盲猪口を用 いるべしと指摘した。1日の唎酒数を 50 点位としたの は, 昭和 47 年ブタペスト市で催された第 1 回世界ワイ ン品評会に於ける実績（63点）と括招むね一致してい る。審査員については，大正 7 年に花岡正庸らが審查成 樍を統一するために技術官を審査員に加えるべきである と提唱し, 次第にその数を増し, 吟醕酒を最高の品質と 評価する方向に進んだ。この全国品評会は 2 年毎に開か れたが，昭和 13 年第 16 回をるって戦時の故に中止さ れ, 戦後は日本酒造組合中央会が主催して 27 年秋から 行なったが 33 年の第 4 回で中止された。これらの品評 会の目的は酒質向上であったから結果が毎回, 前回より も品質は向上したと評され続けてきたのは技術の進歩と して自然である。然し，ワインブームなとと叫ばれてい る当今, 50 年前の大正 12 年に秀徳会第 2 回公開酒類品 評会に扮いて鹿又親審査長が「元来, 近来の醇良清酒は 白ワインないしシェリー酒の風味に類似しかけているの で, 本品評会はこのような新傾向を具備した清酒を選ん で市場に紹介する」とし，明確に目的を定めたような品 評会もあったことを付記しておく。

試験所主催の 全国新酒 鑑評会はほとんど毎年行なわ れ, 昭和 49 年 4 月で第 61 回を了した。この鑑評会も 次第に吟醸酒偏重の方向に進み, 特に昭和 40 年頃から は，吟醉香を装飾する加工技術が現われ，酸度は減少し て清酒の風格を失うあのが多くなったので, 49 年には ガスクロマト分析を行なってこれらを排除し，かつ酸度 の多少によって出品酒を数群に分類し, 各群別に唎酒す るという新しい方法を行なった。酸度の逐年減少は市眅 清酒でも見られるが赀好领料の本命として問題があり， それ以上に重要な発酵化学上の問題を含んでいる。品評 会であれ鑑評会であれ，無差別同列に配列して唎酒するる :鑑評法は不合理である。それは諸外国にも例が少なく多 様化し高級化し国際化する消費者搘好の流れにる添わな いからである。そのほか試験所で行なっている鑑評会に は, 昭和 37 年以来毎年秋の全国洋酒鑑評会があり, 国 産洋酒類の品質向上飞大きく寄与している。

\section{おわりに}

永年の醇造技術の進歩をかけ足で解説したが，これは ひとり試験所だけではなく関係諸学会・諸試験研究機関 による御支援の足跡でもある。顧みてこの 70 年, わが 国は初めの 50 年を相次ぐ戦乱と復興の間に過し, 後の 20 年間ようやく佰久の平和を迎兄て人々の価値観は変 動している。ドイッ人医師ケンペルの日本誌（1727 年） も明治初期の外国人御雇教師たちも共に世界に比類なし と絶讃してやまなかった伝統的酒造技術であるが，その 後の技術が，外国人が先にその価值を認めてからわれわ れがこれに従らといら明治以来の文化発展の後進的パタ 一ンの外で，独自に発展してきたことを銘じなければな らないと同時に, 現代は種々の外国起源の酒が各々強い 伝統的個性を競って共存し消費を増大しつつあるのが現 実であることを忘れてはならない。

敢えて世界に先がけて数々の化学調味料を発明した例 を举げるまであなく，人々のううさの感覚は抜群であ り，それは 1,000 年以上にも亘って磨きにみがかれた貴 重な国民の能力である。国土は狭く資源は少なく国際間 の協力を不可避とするわが国は, 自ら好むと否とにかか わりなく今後いろいろな社会経済上の変化に遭遇すると 思われるが，常に自らの文化（能力）を高めることによ ってその栄光を保持することができるであろう。䁔造業 もまたその例外ではない。そして䁔造技術においても， ひとり日本酒だけではなく，この尊い能力の根源を培っ てきた伝統的技術を近代科学の眼で追究することから出 発して，そこから新しい平和の時代にふさわしい技術の 開花が期待されるのではなかららか。このときに当り, 初代所長目賀田種太郎（主税局長）が, 幕末に海外列強 の間にあって冷静に独立平和開国を成し遂げた勝海舟の 女婿であったことを思うことは，ひとり筆者だけの感傷 ではあるまい。

明治 37 年日露戦争のさなかに大蔵省に創設された醉 造試験所は, 現在世界にも数少ない酲造技術の専門試験 研究機関として国家国民の大きい期待のもとに試験と研 究を併行し，常に時代に敏感なヤングを受け入れて刷新 と脱皮をくり返しつつ業務を遂行してきた。あらためて 関係各位の温かい御協力に感謝しなければならないし， 同時に戦後の廃墟の中から今日を築き上げるべく多大の 御努力をいたたいた山田正一博士（元所長）はじめ先輩 各位に敬意を表し，併せて今後とも読者の皆さんから かわらない御支援をいたたくことを切に願ら次第であ る。 